\title{
Interdecadal Change in the Intensity of Interannual Variation of Spring Precipitation over Southern China and Possible Reasons
}

\author{
CHAO XU \\ School of Atmospheric Sciences/Center for Monsoon and Environment Research/Guangdong Province Key \\ Laboratory for Climate Change and Natural Disaster Studies, Sun Yat-sen University, Guangzhou, and Three \\ Gorges New Energy Shantou Power Generation Co., Ltd., Shantou, China \\ YUNTING QIAO AND MAOQIU JIAN \\ School of Atmospheric Sciences/Center for Monsoon and Environment Research/Guangdong Province Key \\ Laboratory for Climate Change and Natural Disaster Studies, Sun Yat-sen University, Guangzhou, and \\ Southern Marine Science and Engineering Guangdong Laboratory (Zhuhai), Zhuhai, China
}

(Manuscript received 5 June 2018, in final form 21 April 2019)

\begin{abstract}
The intensity of interannual variation of spring precipitation over southern China during 1979-2014 and possible reasons for it are investigated in this paper. There is a significant interdecadal change in the intensity of interannual variation of spring precipitation over southern China around 1995/96. The intensity of interannual variation of spring rainfall over South China is stronger during 1979-95 than that during 1996-2014. The possible reason may be the larger amplitude of the sea surface temperature anomaly (SSTA) in the western Pacific Ocean (WP) before 1995/96. The cooler (warmer) SSTA in WP may trigger an abnormal local anticyclone (cyclone) at lower levels. The anomalous southwesterly (northeasterly) flow at the northwestern flank of the WP anticyclone (cyclone) covers South China, transporting more (less) moisture to South China. Meanwhile, the anomalous winds converge (diverge) in South China at lower levels and diverge (converge) at upper levels, which causes the anomalous ascent (descent) to enhance (reduce) the precipitation over there. However, during 1996-2014, the intensity of interannual variation of spring rainfall over the middle and lower reaches of the Yangtze River valley becomes much stronger than that during 1979-95, which is related to the intensified interannual variation of the atmospheric circulation in the middle and high latitudes over Eurasia. The weak (strong) Siberian high and East Asian trough may reduce (enhance) the northerly wind from the middle and high latitudes. As a result, the middle and lower reaches of the Yangtze River valley are subjected to the anomalous southerly wind, favoring more (less) precipitation over there.
\end{abstract}

\section{Introduction}

Summer [June-August (JJA)] is the major rainy season over eastern China (Ding 1992; Qian and Lee 2000). Compared with summer precipitation, the research that focuses on spring [March-May (MAM)] precipitation is less. However, in southern China, spring is also a significant rainy season (Cheng et al. 2018). Wu and Mao (2016) noted that the MAM total rainfall exceeds $500 \mathrm{~mm}$ over South China, contributing more than 35\% of the annual total precipitation over this area (Yang and Lau 2004). Furthermore, spring is the right time for seed sowing and germinating, so the amount of spring precipitation over southern China will directly affect the

Corresponding author: Yunting Qiao, qiaoyt@mail.sysu.edu.cn agricultural production of China. Thus, understanding the variations of spring precipitation over southern China is of great importance to the people's life and production.

The variations of spring rainfall over southern China occur on multiple time scales, of which interannual variability is the primary one ( $\mathrm{Liu}$ et al. 2015; $\mathrm{Li}$ and Zhang 2013). Scientists have already done many studies to reveal the interannual variation of spring precipitation over southern China (Jiang and Zhao 2012; Liu et al. 2015; Zhang and You 2010; Zuo and Zhang 2012). $\mathrm{Li}$ and Zhang (2013) used the power spectral analysis method to calculate the variance proportions of different time scale variations of spring precipitation over the middle and lower reaches of the Yangtze River valley and found that the interannual variation accounts for 
$78.9 \%$ of the total variance. Zhang et al. (2009) revealed the spatial distribution characters of spring rainfall in China during 1951-99 through empirical orthogonal function (EOF) analysis and found that the EOF1 reflects the antiphase variations of spring precipitation over South China and Huaihe River Valley. Zuo and Zhang (2012) found that the interannual variability of spring rainfall is notable and becomes intensified after the late 1980s. Many scientists also revealed the characteristics of spring precipitation over southern China on the interdecadal time scale (Jiang and Zhao 2012; Zuo et al. 2012a; Zhu et al. 2014). Jiang and Zhao (2012) pointed out that the spring precipitation over southern China was less in the middle and late 1960s and greater in the middle 1970s to the early 1980s, compared with the climatological mean. The spring precipitation began decreasing from the early 1990s again. The spring rainfall has reduced $30 \%$ over southern China after the early 1990s (Zuo et al. 2012a). Zhu et al. (2014) also found that the spring precipitation over southern China experienced an interdecadal change with the rainfall decreasing after 1994, which has an out-of-phase relationship with summer precipitation.

With regard to influencing factors of spring precipitation, related factors from the middle and high latitudes to the tropics have been found (Yang and Lau 2004; Wu and Kirtman 2007; Wan et al. 2009; Zhang et al. 2009; Bai et al. 2011; Shao and Zhang 2012; Zuo and Zhang 2012; Zuo et al. 2012a,b; Chen et al. 2014; Li and Zhang 2013; $\mathrm{Wu}$ and Mao 2016; Jia et al. 2018). Atmospheric water vapor transport influences the typical anomalous rainfall pattern in China in both spring and summer (Zhou and Yu 2005; Zhang et al. 2009). During the wetter spring over South China, the southwesterly transports water vapor along the northwest flank of western Pacific subtropical high, which is similar to the water vapor transport anomalies in the wetter summer over South China. Yang and Lau (2004) found that the sea surface temperature anomaly (SSTA) in western tropical Pacific is usually below normal when there is a positive SSTA in the central and eastern tropical Pacific and Indian Ocean, and the western Pacific subtropical high tends to remain in the south, which may enhance the precipitation over southern China by bringing more water vapor through the strong southeast winds along the edge of subtropical high. Zuo and Zhang (2012) also pointed out that the positive SSTA in the central and eastern tropical Pacific and negative SSTA in the western Pacific (WP) can trigger negative WP pattern [so named by Wallace and Gutzler (1981)] and weaken the meridional circulation in the middle and high latitudes, so that the southerly wind at lower levels can reach eastern China more easily, which enhances spring rainfall over there. Chen et al. (2014) noted that the SSTA in the central tropical Pacific and south Indian Ocean can influence the spring precipitation in South China by abnormal vertical circulation. Besides the SSTA, the Madden-Julian oscillation (MJO) in the tropics is also an important factor influencing the spring precipitation over southern China. There is a positive rainfall anomaly in the middle and lower reaches of the Yangtze River valley when the MJO shifts eastward to the mideastern Indian Ocean, and positive precipitation over southern China when the MJO moves to the IndoChina Peninsula and Indonesia (Bai et al. 2011). In the middle and high latitudes, the Tibetan Plateau can influence the spring rainfall over southern China with its dynamic and thermal forcing (Wan et al. 2009). Also, snow cover in Eurasia has great impact on rainfall over southern China by influencing the atmospheric circulation anomaly in the middle and high latitudes via triggering an abnormal wave train (Wu and Kirtman 2007; Zuo et al. 2012a; Jia et al. 2018). When western Siberian spring snow coverage gets larger, spring rainfall over South China is usually above normal (Wu and Kirtman 2007). There is a similar positive relationship between spring rainfall over South China and the North Atlantic Oscillation (NAO): the precipitation over South China is enhanced when the NAO is at its positive phase (Shao and Zhang 2012). Recently, Jia et al. (2018) emphasized the important impact of the snow cover extent anomalies around Lake Baikal on spring precipitation over southern China. Furthermore, the snow cover extent anomalies around Lake Baikal correlate with the different variation of spring precipitation over southern China before and after the late 1980s.

However, most of the previous research focused on the interannual and interdecadal variation of spring precipitation amount over southern China. There has been little research about the intensity of interannual variation of spring precipitation over southern China. Understanding the change of the intensity of interannual variation may be important for increasing predictability of precipitation (Sun and Wang 2013). Scientists have already found that there is a significant interdecadal increase in the intensity of interannual variation of summer precipitation over South China around early 1990s (Fan et al. 2014; Chen et al. 2017). Fan et al. (2014) pointed out that the remarkable increase in spring snow depth over the southeastern Tibetan Plateau plays an important role in the interdecadal increase in the intensity of interannual variation of summer precipitation over South China. Chen et al. (2017) emphasized the interdecadal increase of the intensity of interannual variability in tropical eastern Indian Ocean SST. In addition, the influence of a coupled mode of the NAO and North Atlantic tripole SST anomaly is also an important factor. 
Since the intensity of interannual variation of South China summer rainfall experienced a remarkable increase after early 1990s, is there a similar interdecadal variation in the intensity of interannual variation of spring precipitation over southern China? If so, what is the forcing factors contributing to this interdecadal change? Our study aims to answer these questions by analyzing observed data and several reanalysis datasets. The rest of this paper is organized as follows. Section 2 describes the data and analysis methods. The interdecadal change in the intensity of interannual variation of spring precipitation over southern China is investigated in section 3. Section 4 discusses the possible reasons that cause the interdecadal variation of the intensity of interannual variation from the perspective of atmospheric circulation and SST variability. Finally, a summary and discussion are given in section 5 .

\section{Datasets, methods, and model}

The present study employs monthly rainfall of 756 stations in the mainland of China covering the period 1979-2014, provided by the Chinese Meteorological Data (CMD) Service Network. The monthly variables, such as zonal wind, meridional wind, vertical velocity, air temperature, geopotential height, relative humidity, specific humidity, and potential vorticity are obtained from the European Centre for Medium-Range Weather Forecasts (ECMWF) interim reanalysis (ERA-Interim; Dee et al. 2011) dataset with a horizontal resolution of $1^{\circ}$ in both the zonal and meridional directions, spanning the period from 1979 to 2014 . We used the monthly mean SST and sea ice data from Hadley Centre Sea Ice and Sea Surface Temperature dataset (HadISST) with horizontal resolution of $1^{\circ} \times 1^{\circ}$ (Rayner et al. 2003) from 1979 to 2014.

To exclude the possible impact of interdecadal variation, the components with the periods exceeding 8 years are first removed by using the Fourier harmonics analysis. All the data and indices used in the present study are the interannual components without specific description and significance is tested based on the Student's $t$ test. The 9-yr running standard deviation of interannual component represents the evolution of the intensity of interannual variation ( $\mathrm{Lu}$ and Fu 2010; Fu 2013, 2015). Empirical orthogonal functions are applied to extract the leading mode of the intensity of interannual variation in spring precipitation over southern China $\left(20^{\circ}-35^{\circ} \mathrm{N}, 105^{\circ}-125^{\circ} \mathrm{E}\right)$ during 1979-2014. Southern China is a vast region including South China and the middle and lower reaches of the Yangtze River valley.

Furthermore, we use moist potential vorticity (MPV) to explain the influence of convective activity. MPV is a comprehensive quantity reflecting the dynamic and thermal properties of atmosphere, and it also considered the influence of water vapor ( $\mathrm{Li}$ et al. 2016; Wu et al. 1995). So, we can use MPV to reveal the mechanism of precipitation. Wu et al. (1995) noted the conservation equation of the moist potential vorticity [Eq. (1)], in which $\zeta_{p}$ represents relative vorticity, $f$ is the Coriolis parameter, $g$ is the acceleration of gravity, and $\theta_{\text {se }}$ is pseudoequivalent potential temperature. MPV can be divided into two components. The vertical component of moist potential vorticity [MPV1, Eq. (2)] can indicate the convective stability of atmosphere; when the atmosphere is convectively unstable, MPV1 $<0$. MPV2 [Eq. (3)] is the horizontal component of moist potential vorticity; positive MPV2 can indicate the activity of warm and wet flow.

$$
\begin{aligned}
\text { MPV } & =-g\left(\zeta_{p}+f\right) \frac{\partial \theta_{\text {se }}}{\partial p}+g\left(\frac{\partial v}{\partial p} \frac{\partial \theta_{\text {se }}}{\partial x}-\frac{\partial u}{\partial p} \frac{\partial \theta_{\text {se }}}{\partial y}\right) \\
& =\text { const }, \\
\text { MPV1 } & =-g\left(\zeta_{p}+f\right) \frac{\partial \theta_{\text {se }}}{\partial p}, \quad \text { and } \\
\text { MPV2 } & =g\left(\frac{\partial v}{\partial p} \frac{\partial \theta_{\text {se }}}{\partial x}-\frac{\partial u}{\partial p} \frac{\partial \theta_{\text {se }}}{\partial y}\right) .
\end{aligned}
$$

The Community Atmosphere Model version 4 (CAM4) developed with significant community collaboration at the National Center for Atmospheric Research (Neale et al. 2013) is used in this study, which was also released as part of the Community Climate System Model, version 4 (CCSM4) (Gent et al. 2011). The CAM4 can reasonably capture the climatological characteristics and have improvements on CAM3 in tropical precipitation distributions and tropospheric humidity distributions (e.g., Neale et al. 2013). In this paper, the CAM4 model uses a finite volume dynamic core with a horizontal resolution of roughly $0.9^{\circ}$ latitude $\times 1.25^{\circ}$ longitude, and with 26 vertical levels from the surface to approximately $3.5 \mathrm{hPa}$.

\section{Interdecadal change in the intensity of interannual variation of spring precipitation over southern China}

To explore the spatial and temporal characteristics in the intensity of interannual variation of spring precipitation, the EOF analysis is applied to the 9-yr running standard deviation of spring precipitation over southern China during 1979-2014 (shown as Fig. 1). The first EOF mode is statistically well separated from the other EOF modes according to the rule of thumb by North et al. (1982). The first EOF mode accounts for $36.84 \%$ of the 


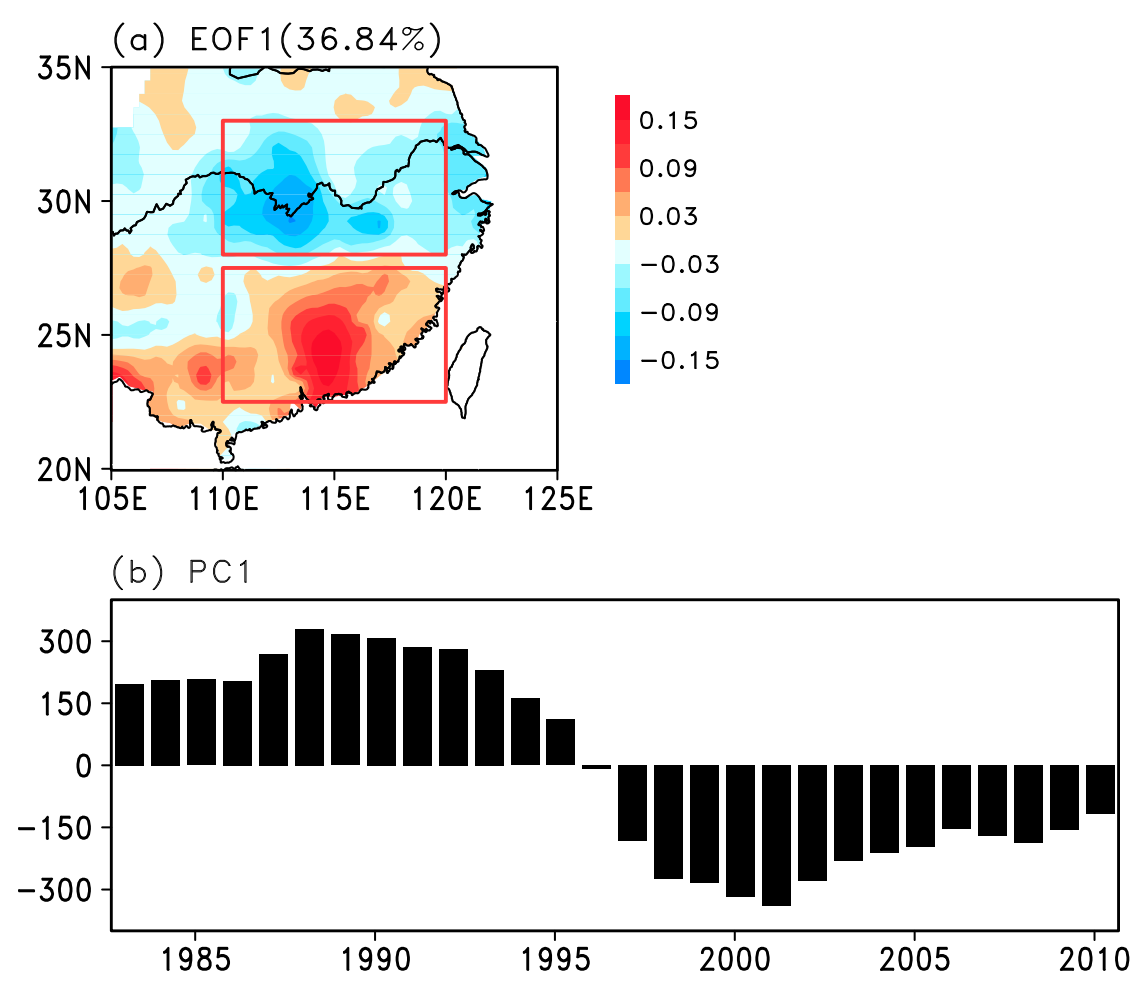

FIG. 1. (a) The first EOF mode (shaded) and (b) the corresponding principal component (PC) of the intensity of interannual variation in spring precipitation over southern China $\left(20^{\circ}-35^{\circ} \mathrm{N}, 105^{\circ}-125^{\circ} \mathrm{E}\right)$ during $1979-2014$.

total variance. In EOF1 (Fig. 1a), an apparent positive anomaly center is located over South China $\left(22.5^{\circ}-\right.$ $\left.27.5^{\circ} \mathrm{N}, 110^{\circ}-120^{\circ} \mathrm{E}\right)$, while the middle and lower reaches of the Yangtze River valley $\left(28^{\circ}-33^{\circ} \mathrm{N}, 110^{\circ}-120^{\circ} \mathrm{E}\right)$ are the negative anomaly center. The zero contours locate around the latitude of $27^{\circ} \mathrm{N}$, which means the intensity of interannual variation of spring rainfall over South China and the middle and lower reaches of the Yangtze River valley is antiphase. From the first principal component (PC1) (Fig. 1b) we can see a remarkable interdecadal shift from positive to negative values around 1995/96, which indicates that there is an interdecadal change in the intensity of interannual variation of spring precipitation over southern China around 1995/96. The intensity of interannual variation of spring precipitation over South China is stronger before 1995/96, whereas that over the middle and lower reaches of the Yangtze River valley is much stronger after 1995/96.

To further investigate the interdecadal change of the intensity of interannual variation in spring rainfall over southern China, we calculated the standard deviation (STD) of the interannual component of spring precipitation over southern China before 1995/96 (1979-95) and after 1995/96 (1996-2014), respectively (Fig. 2). During 1979-95, the maximum center of STD is located over South China with a value greater than $210 \mathrm{~mm}$ (Fig. 2a), which means the large STD of South China spring rainfall is dominant in this period. During 19962014, there are two maximum centers in southern China. One center is situated over the coastal area of South China. However, the region of this center is very small. The main maximum center of STD is located over the middle and lower reaches of the Yangtze River valley with the center value above $200 \mathrm{~mm}$, which indicates that the STD of spring precipitation over the middle and lower reaches of the Yangtze River valley becomes dominant during 1996-2014 (Fig. 2b). And we can also see the interdecadal change in the intensity of interannual variation from the time series of the interannual component of spring precipitation over South China and the middle and lower reaches of the Yangtze River valley (Figs. 2c,d). The STD of spring precipitation over South China is $115.42 \mathrm{~mm}$ during $1979-95$, whereas the value during 1996-2014 is $90.42 \mathrm{~mm}$. Although the difference of STD in the two periods is below the $90 \%$ confidence level according to the $F$ test, considering the spatial distribution of STD (Fig. 2a) we can suggest that the amplitude of spring precipitation over South China during 1979-95 is stronger than that in 1996-2014. In contrast, the STD of spring precipitation over the middle 

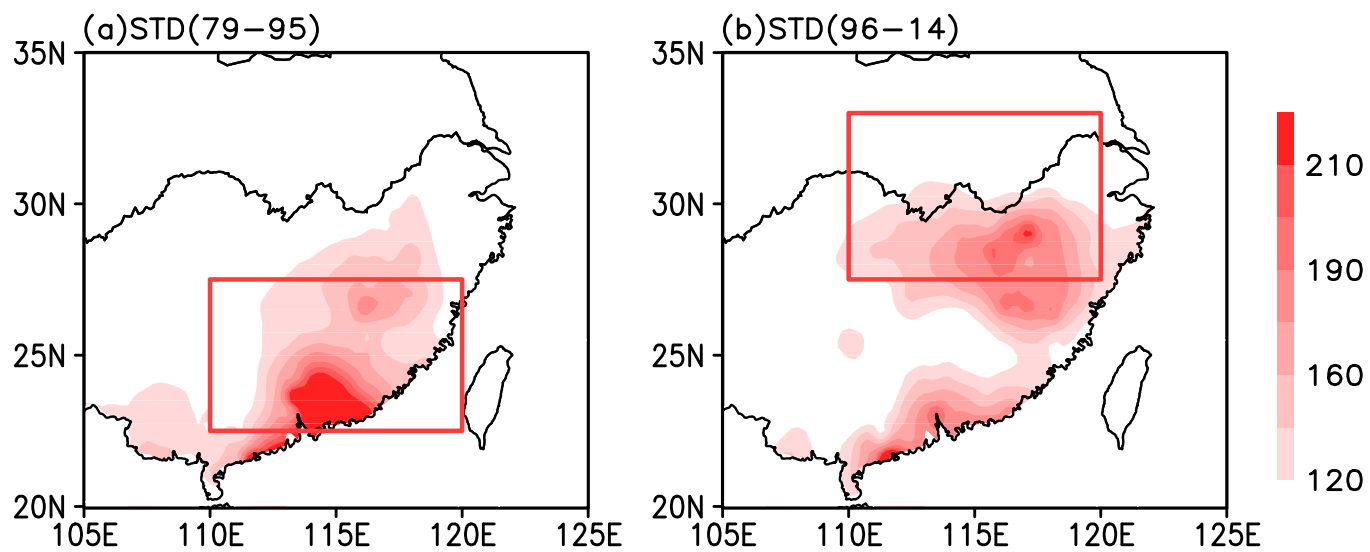

(c)PRE_SC

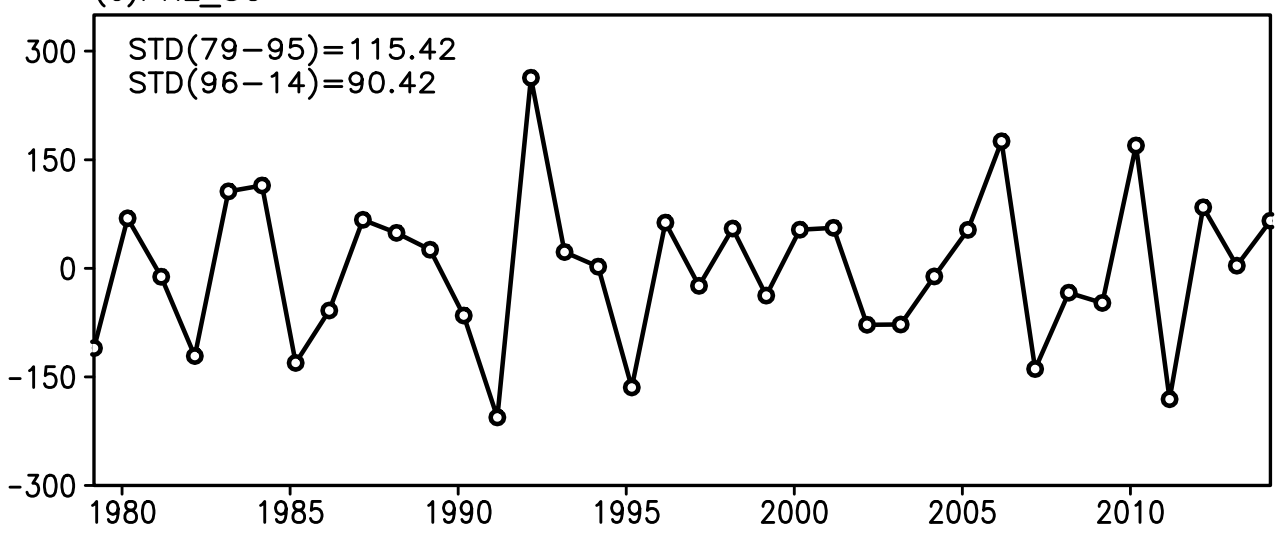

(d)PRE MLYRV

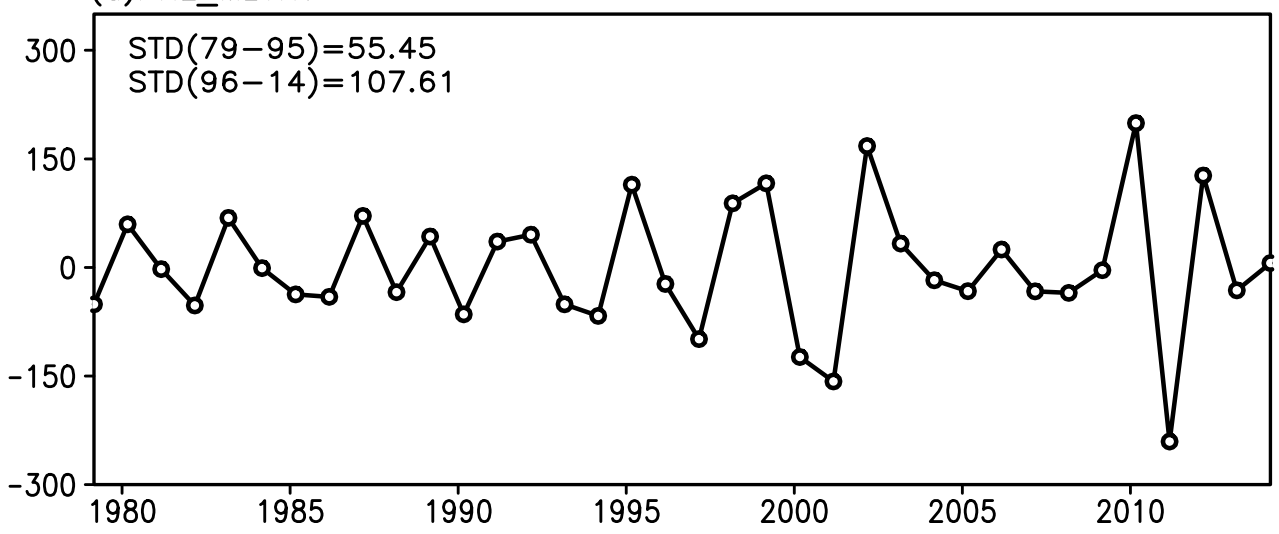

FIG. 2. (a),(b) Spatial distribution of the standard deviation of the interannual component of spring precipitation (mm month ${ }^{-1}$ ) over southern China during 1979-95 and 1996-2014, respectively. (c),(d) Time series of interannual component of spring precipitation $\left(\mathrm{mm} \mathrm{month}{ }^{-1}\right)$ over South China and the middle and lower reaches of the Yangtze River valley, respectively.

and lower reaches of the Yangtze River valley is $55.45 \mathrm{~mm}$ during 1979-95, whereas the value during 1996-2014 is $107.61 \mathrm{~mm}$. The difference of STD between the two periods has exceeded the $95 \%$ confidence level according to the $F$ test, which means that the intensity of interannual variation of spring precipitation over the middle and lower reaches of the Yangtze River valley becomes much stronger during 1996-2014 than during 1979-95.

Vertical motions and divergence of the winds are the direct factors influencing precipitation. Figure 3 shows 

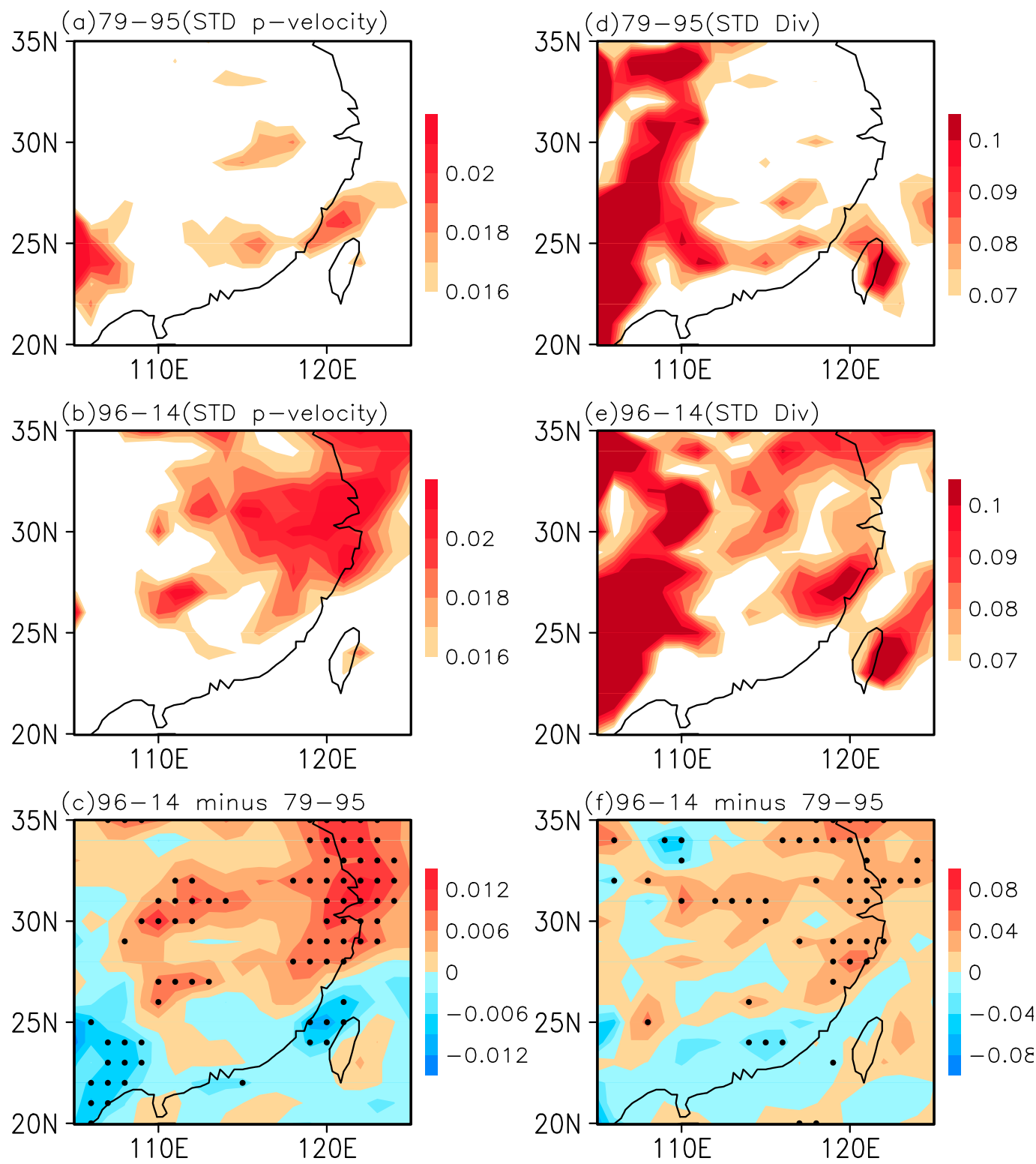

FIG. 3. The standard deviation of the interannual component of (a)-(c) $p$ velocity $\left(\mathrm{hPa} \mathrm{s}^{-1}\right)$ at $500 \mathrm{hPa}$ and (d)-(f) divergence $\left(10^{-5} \mathrm{~s}^{-1}\right)$ at $700 \mathrm{hPa}$ during (top) 1979-95 and (middle) 1996-2014, and (bottom) the difference between these two periods. The dotted areas in (c) and (f) are statistically significant at the significance level of $\alpha=0.05$.

the spatial distribution of the standard deviation of interannual component of vertical $p$ velocity at $500 \mathrm{hPa}$ and divergence at $700 \mathrm{hPa}$ over southern China during 1979-95 and 1996-2014. It is obvious to see that both the STD of the vertical $p$ velocity at $500 \mathrm{hPa}$ and STD of divergence at $700 \mathrm{hPa}$ over South China are larger during 1979-95 than during 1996-2014 (Figs. 3c,f), which is consistent with the interdecadal change of the intensity of interannual variation in spring precipitation over South China. In contrast, the amplitudes of $p$ velocity at $500 \mathrm{hPa}$ and divergence at $700 \mathrm{hPa}$ over the middle and lower reaches of the Yangtze River valley become stronger during 1996-2014 (Figs. 3c,f), just like the variation of the intensity of interannual variation in spring precipitation over the middle and lower reaches of the Yangtze River valley. The interdecadal change in the intensity of interannual variation of spring rainfall over southern China around 1995/96 have so far been described herein. In section 4 we will discuss the possible reasons that cause this interdecadal variation from the perspective of large-scale atmospheric circulation, sea surface temperature, and sea ice variability. 


\section{Possible reasons for the interdecadal change in the intensity of interannual variation of spring rainfall over southern China}

\section{a. Possible reasons for stronger intensity of interannual variation of spring rainfall over South China before 1995/96}

The water vapor transport from the South China Sea and Pacific Ocean is an important factor for the spring precipitation in South China. In the climatology (Fig. 4, vectors), the water vapor is transported from the western Pacific and South China Sea to South China. The easterly wind transports water vapor along the south flank of the western Pacific subtropical high (WPSH), turns to southwesterly over the Indochina Peninsula, and then reaches South China. Thus, we investigate the variation of the zonal water vapor flux at $850 \mathrm{hPa}$. The STD of the zonal water vapor flux over South China, the South China Sea, and the WP is significantly larger before 1995/96 (Fig. 4), suggesting that the intensity of interannual variation of zonal water vapor transport to South China is stronger before 1995/96. As a result, the strong amplitude of zonal water vapor transport to South China before 1995/96 may lead to an intensified interannual variability of spring rainfall over South China. Furthermore, the water vapor transport over the WP may be influenced by the WP SSTA. Is there any remarkable correlation between spring rainfall over South China and WP SST? If so, how does the change of thermal conditions over the WP influence the spring rainfall over South China? Therefore, we investigate the connection between spring rainfall over South China and WP SST.

Figure 5 shows the regression of SST anomalies with respect to the interannual component of spring precipitation over South China during 1979-95. We can see there is a significant negative SST anomaly in WP, which means the positive spring precipitation anomalies in South China is usually accompanied with the cooler SSTA over WP. Then we calculated the average SST in WP $\left(5^{\circ} \mathrm{S}-15^{\circ} \mathrm{N}, 140^{\circ}-170^{\circ} \mathrm{E}\right)$ to indicate the variation of WP SST. Seeing from the time series of normalized interannual component of spring WP SST during 19792014 (Fig. 5b), it is easy to find that the amplitude of spring WP SST is stronger during 1979-95. The STD of WP SST in $1979-95$ is $0.229^{\circ} \mathrm{C}$, whereas it is $0.133^{\circ} \mathrm{C}$ in 1996-2014. The difference of STD between the two periods has exceeded the $95 \%$ confidence level according to the $F$ test, which indicates that the intensity of interannual variation in spring WP SST is stronger during 1979-95, just like it in spring rainfall over South China. So, we suggest that the stronger amplitude of WP
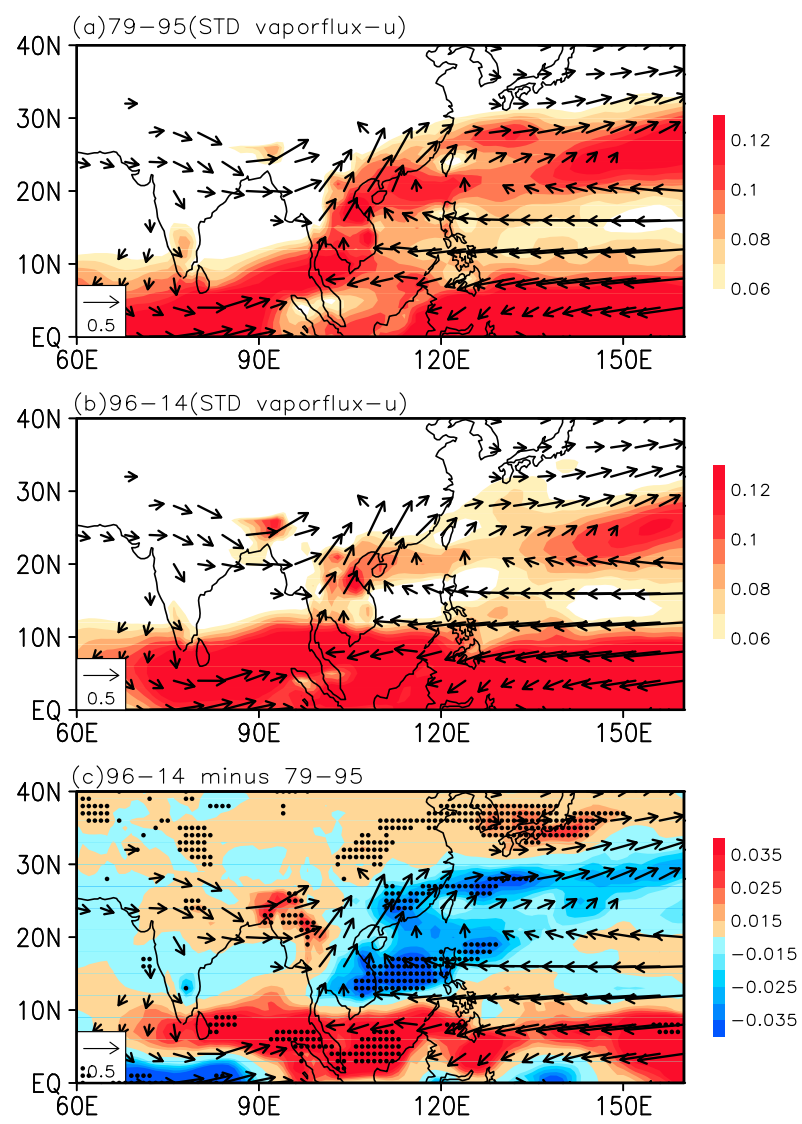

FIG. 4. The climatology of the water vapor flux at $850 \mathrm{hPa}$ (vectors; $10^{-4} \mathrm{~kg} \mathrm{~m}^{-1} \mathrm{hPa}^{-1} \mathrm{~s}^{-1}$ ) and the standard deviation of the interannual component of zonal water vapor flux at $850 \mathrm{hPa}$ (shaded; $10^{-4} \mathrm{~kg} \mathrm{~m}^{-1} \mathrm{hPa}^{-1} \mathrm{~s}^{-1}$ ) during (a) 1979-95 and (b) 19962014, and (c) the difference between these two periods (shaded; $10^{-4} \mathrm{~kg} \mathrm{~m}^{-1} \mathrm{hPa}^{-1} \mathrm{~s}^{-1}$ ). The dotted areas are statistically significant at the significance level of $\alpha=0.05$. Water vapor fluxes less than $0.15 \times 10^{-4} \mathrm{~kg} \mathrm{~m}^{-1} \mathrm{hPa}^{-1} \mathrm{~s}^{-1}$ are not shown.

SST may lead to an intensified interannual variation in spring rainfall over South China during 1979-95.

To explore how the WP SSTA influences the spring rainfall in South China, we investigate some related atmospheric factors. Figure 6 shows the regression of atmospheric circulation with respect to the interannual component of spring WP SST during 1979-95. Considering both Figs. 5 and 6, when SSTA in WP is negative, there is an abnormal lower-level anticyclone over WP (Fig. 6a). Previous studies pointed out that the abnormal anticyclone in WP is triggered by the negative WP SSTA (Wang et al. 2000; Yang and Lau 2004). At the northwestern flank of the WP anticyclone, the anomalous southwesterly is significantly strong, and the anomalous winds converge in South China at $925 \mathrm{hPa}$ (Fig. 6a) and diverge at $200 \mathrm{hPa}$ (Fig. 6b), which causes the anomalous ascent over South China (Fig. 6c). Meanwhile, the easterly wind transports water vapor along the south 

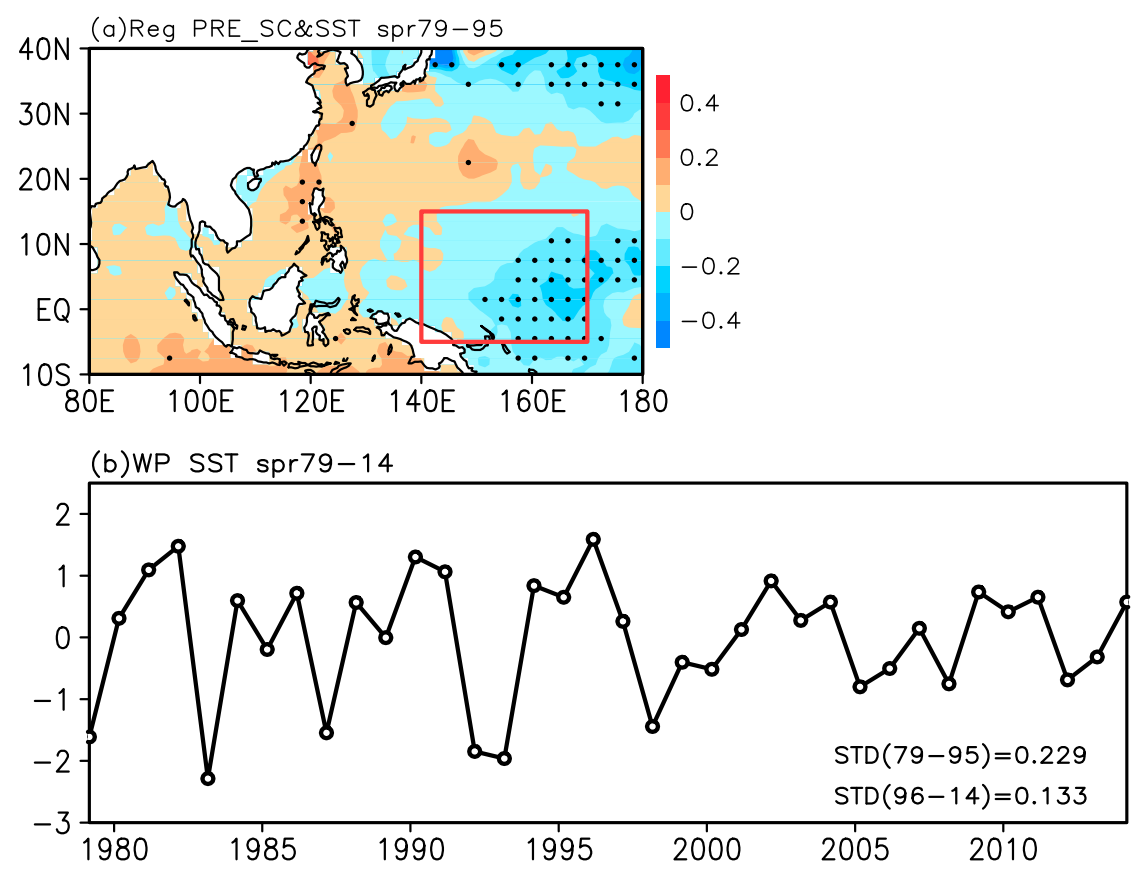

FIG. 5. (a) Spatial distribution of the regression of SST anomalies $\left({ }^{\circ} \mathrm{C}\right)$ with respect to the interannual component of spring precipitation over South China during 1979-95 and (b) time series of the normalized interannual component of spring WP $\left(5^{\circ} \mathrm{S}-15^{\circ} \mathrm{N}, 140^{\circ}-170^{\circ} \mathrm{E}\right) \mathrm{SST}$ during 1979-2014. The dotted areas are statistically significant at the significance level of $\alpha=0.05$.

flank of the WP abnormal anticyclone, turns southwesterly over the Indochina Peninsula, and then reaches South China (Fig. 6d), favoring spring precipitation over there. Therefore, we suggest that the cooler WP SSTA can induce more spring rainfall over South China via triggering abnormal southwesterlies and ascending movement. When the WP SST is warmer, the spring rainfall over South China is less due to the anomalous northeasterly and descending movement. Thus, the stronger interannual variation of WP SST during 1979-95 makes the intensity of interannual variation of spring rainfall over South China stronger in this period.

\section{b. Possible reasons for stronger intensity of interannual variation of spring rainfall over the middle and lower reaches of the Yangtze River valley after 1995/96}

In the section 3 , we find that the intensity of interannual variation of spring rainfall over the middle and lower reaches of the Yangtze River valley becomes significantly stronger after 1995/96. To figure out the possible reasons for the intensification of interannual variation in spring rainfall over the middle and lower reaches of the Yangtze River valley, we try to examine the interdecadal change from the perspective of atmospheric variability. The spring rainfall over the middle and lower reaches of the Yangtze River valley is influenced to a great extent by the cold air from the north. The intensity of the cold air is somehow linked with the circulation systems in the middle and high latitudes ( $\mathrm{Li}$ and Zhang 2013). When the northerly wind is strong, the middle and lower reaches of the Yangtze River valley are covered by cold and dry air, which is unfavorable for precipitation over this area. Figure 7 shows the spatial distribution of the standard deviation of interannual component of geopotential height at $500 \mathrm{hPa}$ and meridional wind at $700 \mathrm{hPa}$ before and after 1995/96. We can see that the STDs of geopotential height over Siberia and East Asia increase after 1995/96, which means the intensities of interannual variation of the Siberian high and East Asian trough become stronger after 1995/96, consistent with the interdecadal change in the intensity of interannual variation of spring precipitation over the middle and lower reaches of the Yangtze River valley. Correspondingly, the amplitude of meridional wind at $700 \mathrm{hPa}$ gets stronger over the region from the southeast of Lake Baikal to the north of the middle and lower reaches of the Yangtze River valley after 1995/96 (Fig. 7f). Therefore, we suggest that the intensified interannual variation of meridional wind over the region from the southeast of Lake Baikal to the north of the middle and lower reaches of the Yangtze River valley, which is caused by the intensified variation of Siberian high and East Asian trough, is a significant 

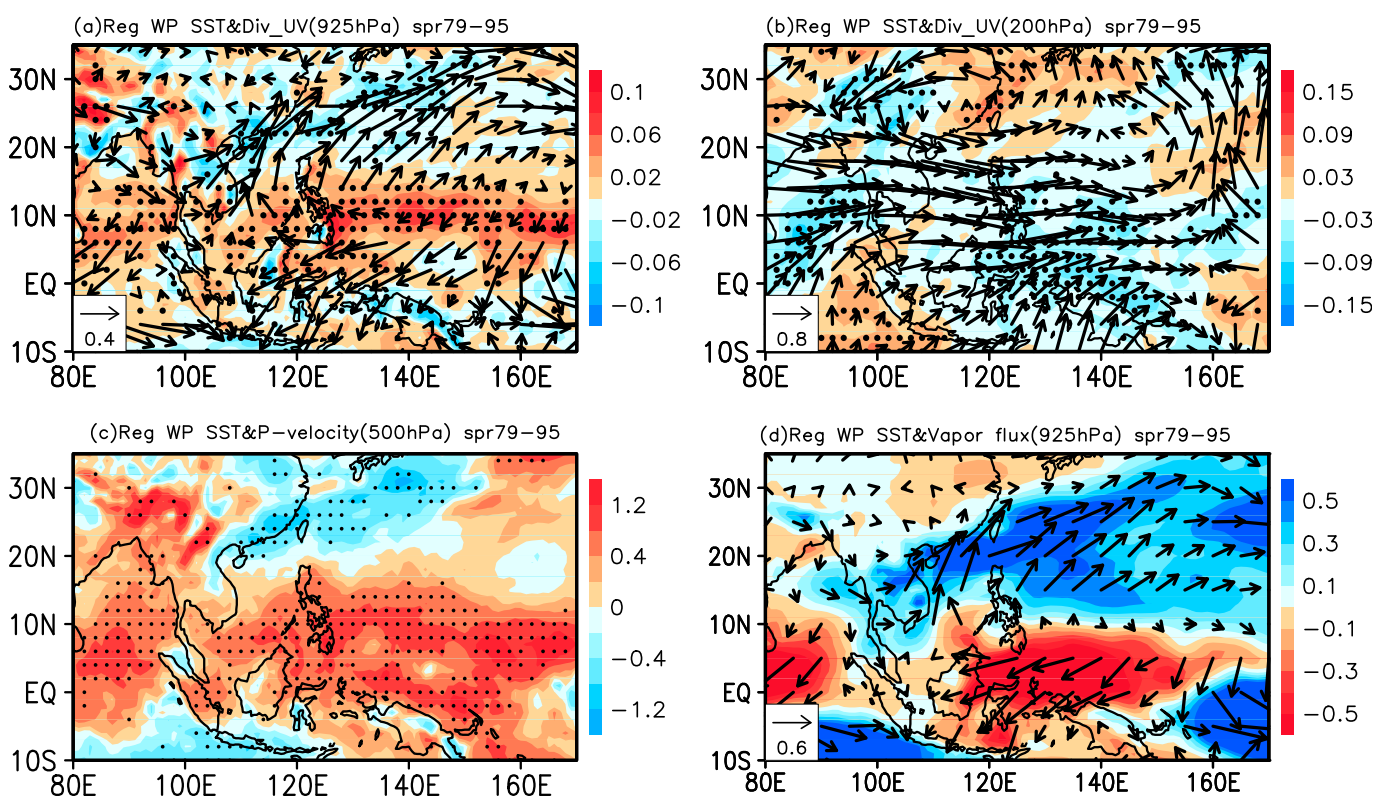

FIG. 6. Regression of winds (vectors; $\mathrm{m} \mathrm{s}^{-1}$ ) and divergence (shaded; $10^{-5} \mathrm{~s}^{-1}$ ) at (a) $925 \mathrm{hPa}$, (b) $200 \mathrm{hPa}$, (c) $p$ velocity (shaded; $10^{-2} \mathrm{hPa} \mathrm{s}^{-1}$ ) at $500 \mathrm{hPa}$, and (d) zonal water vapor flux (shaded; $10^{-2} \mathrm{~kg} \mathrm{~m}^{-1} \mathrm{hPa}^{-1} \mathrm{~s}^{-1}$ ) and water vapor flux vector (vectors; $10^{-2} \mathrm{~kg} \mathrm{~m}^{-1} \mathrm{hPa}^{-1} \mathrm{~s}^{-1}$ ) at $925 \mathrm{hPa}$ with respect to the interannual component of spring WP SST (multiplied by -1) during 1979-95. The dotted areas are statistically significant at the significance level of $\alpha=0.05$.

factor in the interdecadal change in the intensity of interannual variation of spring precipitation over the middle and lower reaches of the Yangtze River valley. Furthermore, we calculated the area average geopotential height at $500 \mathrm{hPa}$ to present the time series of the Siberian high $\left(50^{\circ}-60^{\circ} \mathrm{N}, 80^{\circ}-100^{\circ} \mathrm{E}\right)$ and East Asian trough $\left(38^{\circ}-48^{\circ} \mathrm{N}, 125^{\circ}-150^{\circ} \mathrm{E}\right)$. In addition, we use the average of the meridional wind over the region $35^{\circ}$ $50^{\circ} \mathrm{N}, 100^{\circ}-120^{\circ} \mathrm{E}$ to indicate the intensity of the northerly wind. The interdecadal change of the amplitude around 1995/96 is clear in all the time series (Fig. 8). The differences of STD of the three indices between the two periods have all exceeded the $95 \%$ confidence level according to the $F$ test. This is once again consistent with the intensity of interannual variation of the spring rainfall over the middle and lower reaches of the Yangtze River valley, which further verified the possible linkage between the intensified interannual variation of the spring rainfall over the middle and lower reaches of the Yangtze River valley and the intensity of interannual variation of the mid- and high-latitude systems during 1996-2014.

How do the Siberian high and East Asian trough influence the interannual variability of spring rainfall over the middle and lower reaches of the Yangtze River valley? We calculate the correlation coefficients between the Siberia high, East Asian trough, and area-mean 700-hPa meridional wind over the region $35^{\circ}-50^{\circ} \mathrm{N}, 100^{\circ}-120^{\circ} \mathrm{E}$ and spring rainfall over the middle and lower reaches of the Yangtze River valley during 1996-2014, respectively. The correlation coefficients of the Siberian high, East Asian trough, and 700-hPa meridional wind are $-0.609,0.519$, and 0.601 , respectively. They all pass the significance test at the significance level of $\alpha=0.05$, suggesting a close relationship between the Siberian high, East Asia trough, 700-hPa meridional wind, and spring rainfall over the middle and lower reaches of the Yangtze River valley. To figure out the specific physical process, we composite the atmospheric anomalies for the years with more and less spring rainfall over the middle and lower reaches of the Yangtze River valley. Here, the years of more $(1998,1999,2002,2010,2012)$ and less $(1997,2000,2001,2011)$ rainfall are identified by the criterion that the values of the normalized interannual component of spring precipitation over the middle and lower reaches of the Yangtze River valley exceed \pm 0.75 during 1996-2014. Figure 9 shows the composite difference of geopotential height anomalies at $500 \mathrm{hPa}$, the air temperature, winds, and water vapor transport flux anomalies at $700 \mathrm{hPa}$ between the years of more and less spring rainfall over the middle and lower reaches of the Yangtze River valley. Here, the difference is calculated by more precipitation years minus less precipitation years. During the more precipitation years, the Siberian high is weak and East Asian trough is shallow (Fig. 9a), with the anomalous cyclone located to 

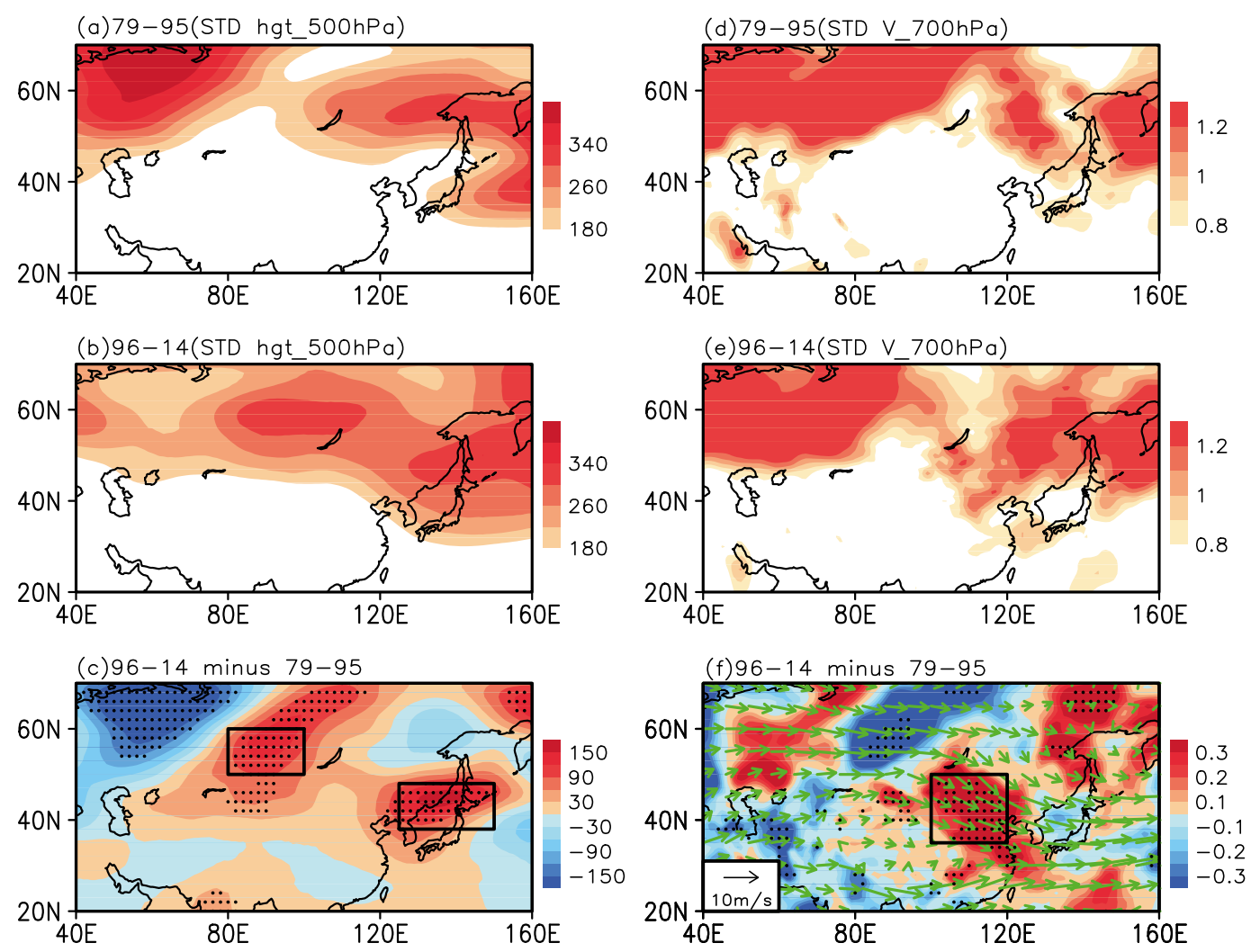

FIG. 7. The standard deviation of the interannual component of (a)-(c) geopotential height at $500 \mathrm{hPa}$ (gpm) and (d)-(f) meridional wind at $700 \mathrm{hPa}\left(\mathrm{m} \mathrm{s}^{-1}\right)$ during 1979-95 and 1996-2014, and the difference between these two periods. The climatological wind at $700 \mathrm{hPa}$ (vectors; $\mathrm{m} \mathrm{s}^{-1}$ ) is shown in (f). The dotted areas are statistically significant at the significance level of $\alpha=0.05$.

the west of Lake Baikal and anomalous anticyclone spanning from East Asia to northwestern Pacific Ocean between $30^{\circ}$ and $45^{\circ} \mathrm{N}$ (Fig. 9b). The anomalous southerly at east flank of this anomalous cyclone and the west of anomalous anticyclone cover the middle and lower reaches of the Yangtze River valley area, which is beneficial for the wet and warm air from tropical ocean to reach the middle and lower reaches of the Yangtze River valley and favorable to the spring rainfall over there (Fig. 9c).

Furthermore, we use moist potential vorticity to explain the influence of convective activity and the movement of cold and warm flow. The specific introduction of MPV can be seen in section 2. Li et al. (2016) pointed out that it is favorable for precipitation when MPV1 at middle levels is negative and MPV2 at lower levels is positive. Figure 10 gives the compositions of MPV1 anomalies at $500 \mathrm{hPa}$ and MPV2 anomalies at $700 \mathrm{hPa}$ for more and less precipitation years over the middle and lower reaches of Yangtze River valley. During the positive years, we can see that MPV1 in the middle and lower reaches of Yangtze River valley is negative (Fig. 10a), which means there is convective instability over the middle and lower reaches of the Yangtze River valley. In the figure of MPV2 (Fig. 10b), the zero contour is located around $29^{\circ} \mathrm{N}$, indicating the confluence of cold and warm flow there. Such a configuration of MPV1 and MPV2 favors the rainfall over the middle and lower reaches of the Yangtze River valley.

Since we find that the intensity of the Siberian high and East Asian trough has great impact on precipitation over the middle and lower reaches of Yangtze River valley, and according to the previous studies the Arctic sea ice has great influence on the atmospheric circulation in the middle and high latitudes (Mysak and Venegas 1998, Wu et al. 1999), we wonder whether sea ice in the Arctic is a forcing factor that caused the interdecadal change in the intensity of interannual variation of spring precipitation over the middle and lower reaches of the Yangtze River valley. First, we investigated the STD of Arctic sea ice in spring and find that the STD in most regions is larger during 1996-2014 than that during 1979-95 (Fig. 11a), which means the intensity of interannual variation of Arctic sea ice is stronger 

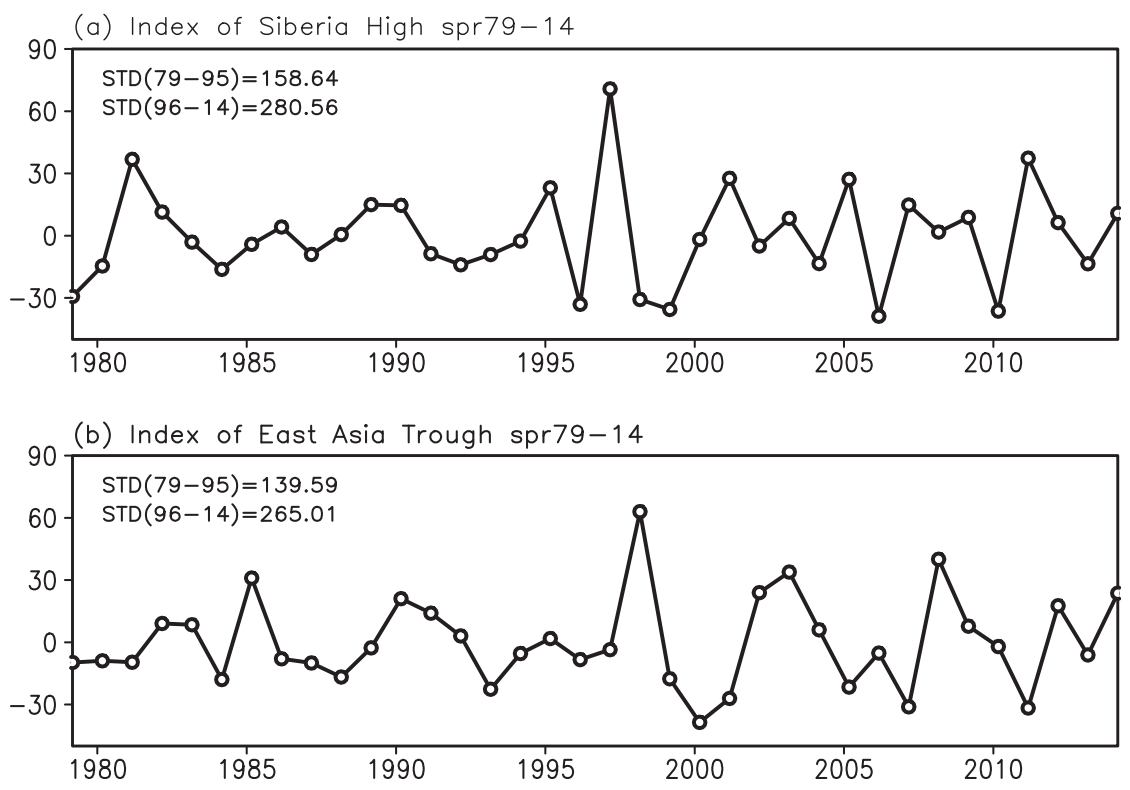

(c) Index of $\mathrm{V}_{-} 700 \mathrm{hPa}$ spr79-14

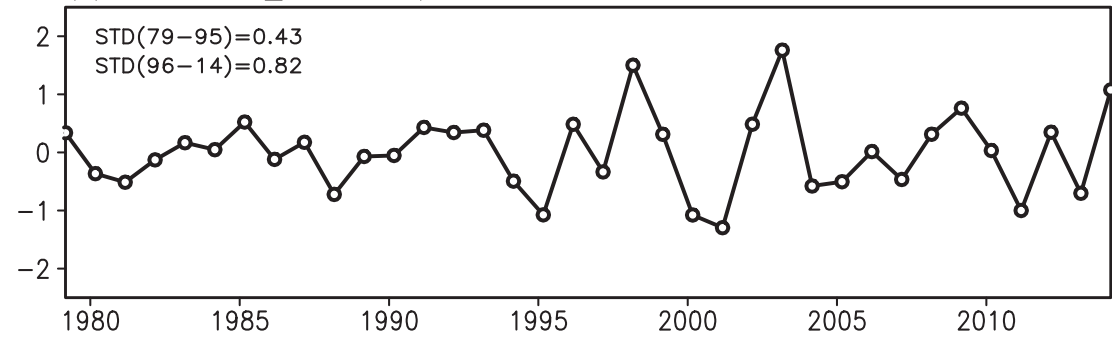

FIG. 8. The time series of the (a) Siberian high (gpm), (b) East Asian trough (gpm), and (c) area-mean meridional wind $\left(\mathrm{m} \mathrm{s}^{-1}\right)$ at $700 \mathrm{hPa}$ over the region $35^{\circ}-50^{\circ} \mathrm{N}, 100^{\circ}-120^{\circ} \mathrm{E}$ during 1979-2014.

during 1996-2014. The change in the Arctic sea ice variability may be related to a warmer mean state in the Arctic region (Fig. 11b) that favors a larger year-to-year change in the ice cover. In addition, we calculated the correlation coefficient between the Siberian high, East Asian trough, and area-mean $700-\mathrm{hPa}$ meridional wind over the region $35^{\circ}-50^{\circ} \mathrm{N}, 100^{\circ}-120^{\circ} \mathrm{E}$ and Arctic sea ice in spring during 1996-2014, respectively (Fig. 12). In Fig. 12a, although there are both positive and negative correlation coefficients, the positive area is larger than the negative area. In Figs. 12b and 12c, the significant negative correlation coefficients are dominant over the Arctic region. The results indicate that when the Arctic sea ice is less, both the Siberian high and East Asian trough are weak, which reduces the cold and dry northerly wind over the region $35^{\circ}-50^{\circ} \mathrm{N}, 100^{\circ}-120^{\circ} \mathrm{E}$.

To further explore how the Arctic sea ice anomaly influences the Eurasian circulation variations, we conducted three experiments using the CAM4 model. The first one is a 35-yr integration forced with climatological mean monthly sea ice from the HadISST dataset, referred to as the control run (CTL). The second one is a $35-y r$ integration forced with climatological mean monthly sea ice plus a sea ice anomaly of 0.005 (referred to as the SIC_P005 experiment) in March-May over the Arctic region $\left(80^{\circ}-90^{\circ} \mathrm{N}, 20^{\circ}-80^{\circ} \mathrm{E}\right)$ since this region is the key region of Arctic sea ice in both Figs. 11 and 12 . The third one is a 35-yr integration forced with climatological mean monthly sea ice plus a sea ice anomaly of 0.01 (referred to as the SIC_P01 experiment) in MarchMay over the Arctic region $\left(80^{\circ}-90^{\circ} \mathrm{N}, 20^{\circ}-80^{\circ} \mathrm{E}\right)$. In this study, we analyze the model results for the last 30 years.

The Arctic sea ice anomaly changes the surface heat exchange between the ocean and the atmosphere. When there is more Arctic sea ice, the surface heat flux is less over the Arctic, and the negative surface heat flux anomaly over Arctic can excite a Rossby wave train at the middle and high latitudes (Honda et al. 2009; Zhang and $\mathrm{Wu}$ 2011). Figure 13 shows composite differences of surface heat flux, 500-hPa geopotential height and wave 
(a) hgt_500hPa

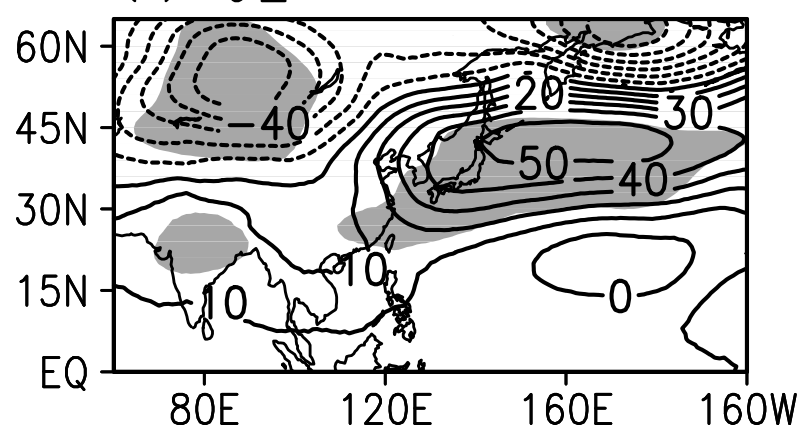

(b) uv_airt_700hPa

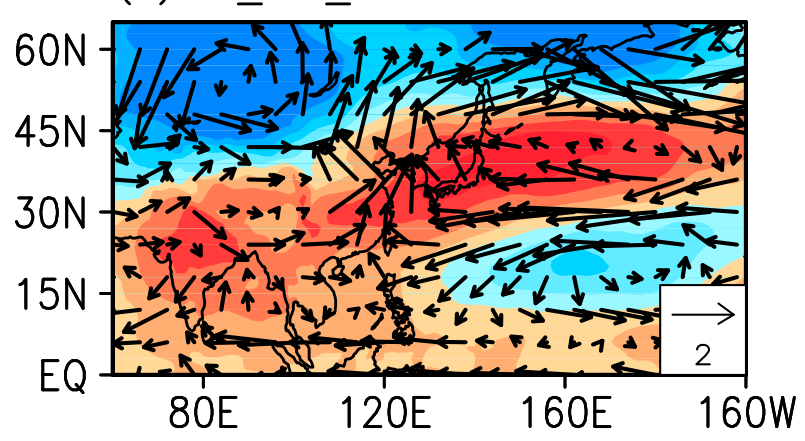

$\begin{array}{lllll}-1.6 & -0.8 & 0 & 0.8 & 1.6\end{array}$

(c) vaporflux_700hPa

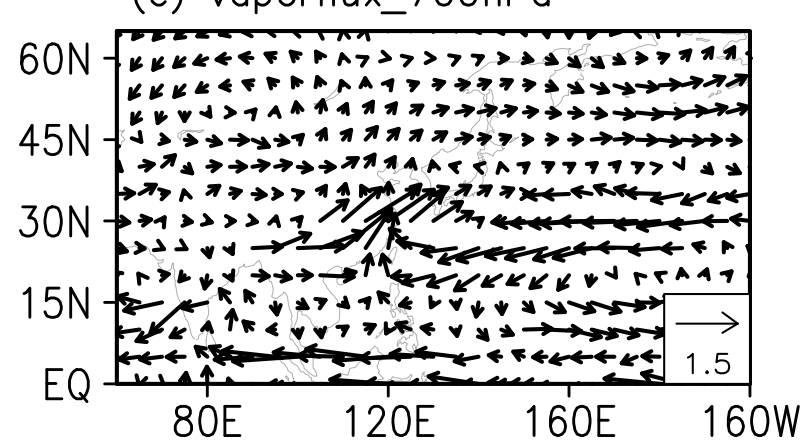

FIG. 9. Composite difference of (a) geopotential height anomalies at $500 \mathrm{hPa}(\mathrm{gpm}),(\mathrm{b})$ air temperature (shaded; ${ }^{\circ} \mathrm{C}$ ) and wind (vectors; $\mathrm{m} \mathrm{s}^{-1}$ ) anomalies at $700 \mathrm{hPa}$, and (c) water vapor flux anomalies (vectors; $10^{-4} \mathrm{~kg} \mathrm{~m}^{-1} \mathrm{hPa}^{-1} \mathrm{~s}^{-1}$ ) at $700 \mathrm{hPa}$ between more and less precipitation years over the middle and lower reaches of Yangtze River valley during 1996-2014. The shaded areas in (a) are statistically significant at the significance level of $\alpha=0.05$.

activity flux, and 700-hPa winds between the different experiments. Here, the wave activity is calculated following the formula in Takaya and Nakamura (2001). Responding to a positive Arctic sea ice anomaly in spring, the surface heat flux shows a negative value over most regions of the Arctic (Fig. 13a), exciting the Rossby wave train over the Eurasia region with the positive geopotential height anomaly over Siberia and negative geopotential height anomaly over East Asia (Fig. 13c). Thus, both the Siberian high and East Asian trough are strong, inducing the strong northerly wind anomaly over East Asia (Fig. 13e). Comparing with Figs. 9a and 9b, we know that the northerly wind anomalies induce less precipitation over the middle and lower reaches of the Yangtze River valley. The differences of surface heat flux, 500-hPa geopotential height, and 700-hPa winds between the SIC_P01 and SIC_P005 experiments are similar to the differences between the SIC_P01 and CTL experiments, once more confirming that intensified sea ice (SIC_P01 compared to SIC_P005) could induce intensified response of atmospheric circulations (Figs. 13b,d,f). Therefore, we suggest that intensified interannual variation of sea ice in Arctic caused the interdecadal enhancement of the intensity of interannual variation in spring rainfall over the middle and lower reaches of the Yangtze River valley by influencing the variation of the Siberian high and East Asian trough.

\section{Summary and discussion}

In this study, we investigate the interdecadal variation in the intensity of interannual variation of spring precipitation over southern China during 1979-2014 and the related large-scale atmospheric and oceanic signal. It is shown that there is a significant interdecadal shift in the intensity of interannual variation of spring precipitation over southern China around 1995/96. Based on the different variation of the intensity of spring rainfall, southern China could be divided into two regions, namely South China and the middle and lower reaches of the Yangtze River valley. The amplitude of spring precipitation over South China during 1979-95 is stronger than that in 1996-2014. In contrast, the intensity of interannual variation of spring precipitation over the middle and lower reaches of the Yangtze River valley becomes much stronger during 1996-2014 than during 1979-95.

The present study shows that the intensity of interannual variation of spring WP SST is stronger during 1979-95 and weaker after 1995/96, which causes the stronger interannual variation of spring rainfall over South China during 1979-95. The WP SSTA has a great impact on the interannual variation of spring precipitation over South China. The anomalous cooler (warmer) SSTA in WP triggers an abnormal lower-level anticyclone (cyclone) over the WP. At the northwestern flank of the WP anticyclone (cyclone), the anomalous southwesterly (northeasterly) is significantly strong, which causes the anomalous wind convergence at the lower level, inducing anomalous ascent (descent) over South China. Meanwhile, the strong southwesterly (northeasterly) is 
(a) MPV1 $500 \mathrm{hPa}$

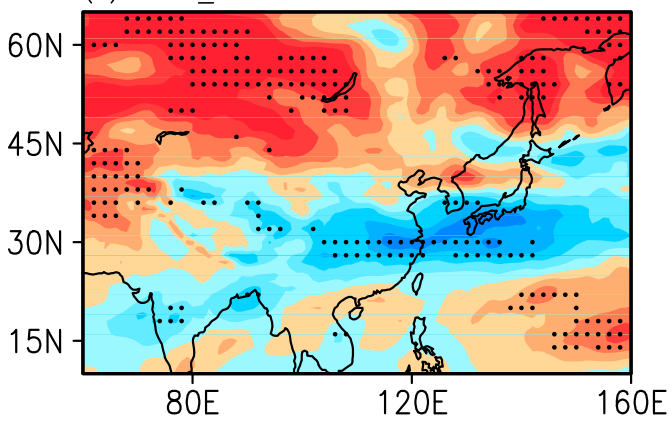

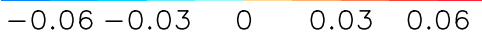

(b) MPV2 $700 \mathrm{hPa}$

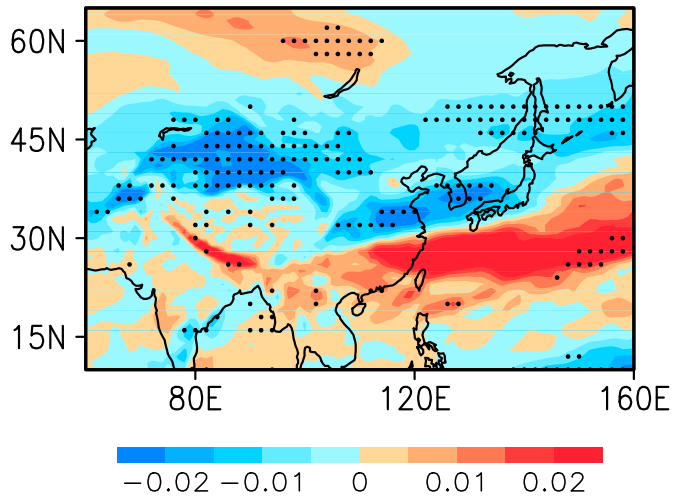

FIG. 10. Composite difference of (a) MPV1 anomalies at $500 \mathrm{hPa}$ and (b) MPV2 at $700 \mathrm{hPa}$ (shaded; $10^{-6} \mathrm{~m}^{2} \mathrm{~s}^{-1} \mathrm{~K} \mathrm{~kg}^{-1}$ ) between years with more and less precipitation over the middle and lower reaches of the Yangtze River valley during 1996-2014. The dotted areas are statistically significant at the significance level of $\alpha=0.05$.

favorable (unfavorable) for the transportation of moisture from Pacific to South China, which enhances (decreases) the spring precipitation over South China.

After 1995/96, the intensity of interannual variation of the Siberian high and East Asian trough and the northerly wind reaching the middle and lower reaches of Yangtze River valley all present a conspicuous interdecadal increase, which may lead to the intensification of interannual variation in spring rainfall over the middle and lower reaches of the Yangtze River valley during 1996-2014. When the Siberian high and East Asian trough are weak (strong), the meridional circulation in the middle and high latitudes will get weaker (stronger), which reduces (enhances) the cold and dry northerly wind reaching the middle and lower reaches of Yangtze River valley. Then the middle and lower reaches of Yangtze River valley are subjected to the anomalous southerly wind, favoring more (less) rainfall over there. Furthermore, we find the intensity of interannual variation of spring sea ice in Arctic during 1996-2014 also increases, which may be a forcing factor out of atmosphere that makes the intensity of interannual variation of spring precipitation over the middle and lower reaches of the Yangtze River valley stronger. When there is an abnormal increase (decrease) in Arctic sea ice, the surface heat flux is weak (strong), which excites the Rossby wave train, and the Siberian high and East Asian trough are stronger (weaker). Correspondingly, there
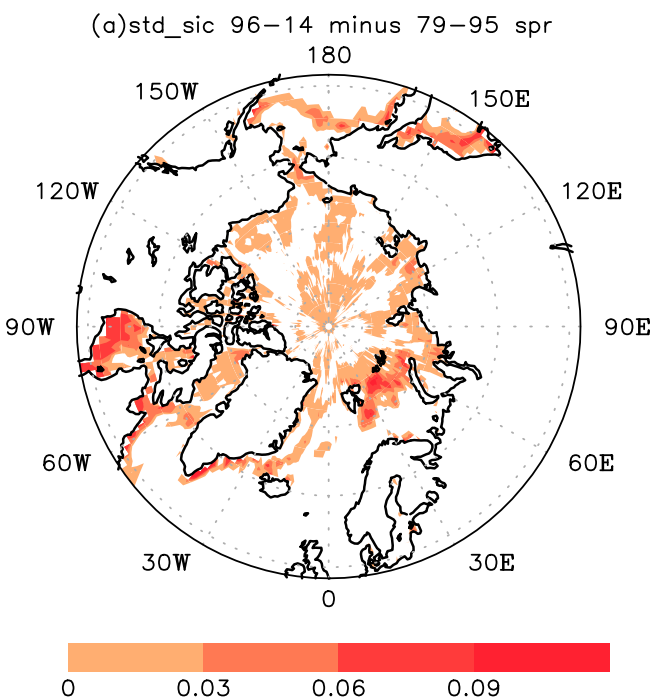

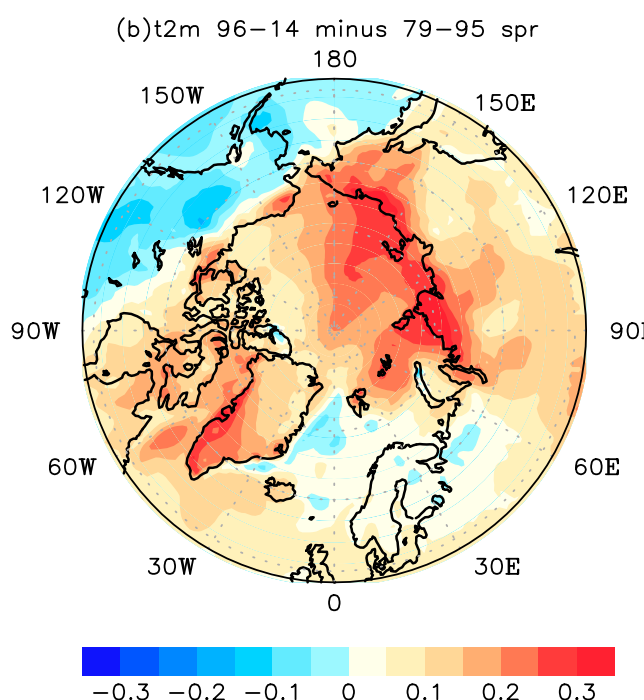

FIG. 11. The difference of the (a) standard deviation of the interannual component of spring sea ice and (b) mean spring air temperature at $2 \mathrm{~m}$ in the Arctic between the 1979-95 period and the 1996-2014 period. 

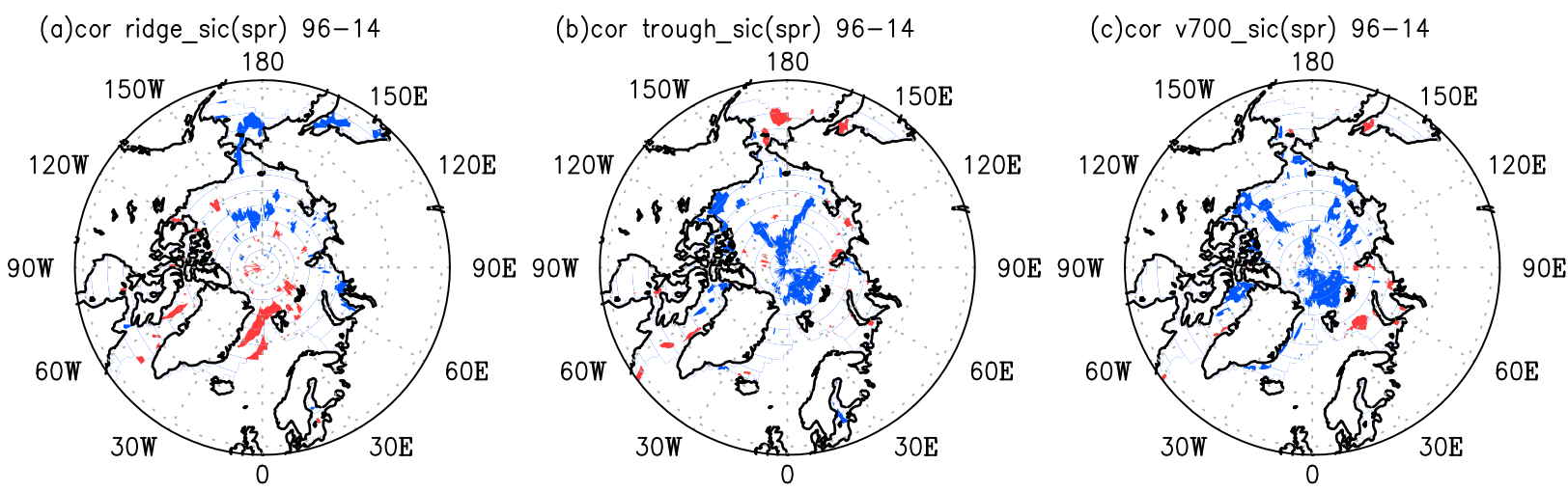

FIG. 12. Spatial distribution of the correlation coefficient between the normalized time series of the interannual component of the (a) Siberian high, (b) East Asian trough, and (c) area-mean 700-hPa meridional wind over the region $35^{\circ}-50^{\circ} \mathrm{N}, 100^{\circ}-120^{\circ} \mathrm{E}$ and $\mathrm{Arctic}$ sea ice in spring during 1996-2014, respectively. The shaded areas are statistically significant at the significance level of $\alpha=0.05$.

will be less (more) spring rainfall over the middle and lower reaches of the Yangtze River valley.

In our study, the major scientific question we focus on is the interdecadal change in the intensity of spring rainfall over South China and the interdecadal change of intensity of spring rainfall over the middle and lower reaches of the Yangtze River valley, respectively. Thus, we explore the possible reasons for the interdecadal change in the intensity of interannual variation of spring precipitation over South China and the middle and lower reaches of the Yangtze River valley separately in section 4.

The comparative intensity of the interannual variability of spring rainfall over South China and the middle and lower reaches of the Yangtze River valley are different during 1979-95 and during 1996-2014. During 1979-95, the intensity of the interannual variability of spring rainfall over South China is larger than that over the middle and lower reaches of the Yangtze River valley. In contrast, during 1996-2014, the intensity of the interannual variability of spring rainfall over the middle and lower reaches of the Yangtze River valley is larger than that over South China. Here, we would like to also discuss the possible reasons for the comparative intensity during 1979-95 and during 1996-2014. During 1979-95, the intensity of WP SST anomaly is strong, and correspondingly the variation of atmospheric circulations at low latitudes is strong (Figs. 4 and 5). However, the intensity of Arctic sea ice anomaly is weak during this period; correspondingly, the variation of atmospheric circulations over the middle and high latitudes including the Siberian high, East Asian trough, and the meridional wind over the region $35^{\circ}-50^{\circ} \mathrm{N}, 100^{\circ}-120^{\circ} \mathrm{E}$ is weak (Figs. 7 and 8). Thus, the WP SST and the atmospheric circulation at low latitudes play more important role with regard to the spring rainfall over southern
China than the atmospheric circulation at the middle and high latitudes during 1979-95. Since the variation of spring rainfall over South China is more sensitive to the low-latitude systems, the intensity of the spring rainfall over South China is stronger than that over the middle and lower reaches of the Yangtze River valley. During 1996-2014, the intensity of Arctic sea ice anomaly becomes strong; correspondingly, the variation of atmospheric circulations over the middle and high latitudes including the Siberian high, East Asian trough, and the meridional wind over the region $35^{\circ}-50^{\circ} \mathrm{N}, 100^{\circ}-120^{\circ} \mathrm{E}$ is strong (Figs. 7 and 8). Meanwhile, the intensity of the WP SST anomaly is weak; correspondingly, the variation of atmospheric circulations at the low latitude is weak (Figs. 4 and 5). The Siberian high, East Asian trough, and meridional wind over the region $35^{\circ}-50^{\circ} \mathrm{N}$, $100^{\circ}-120^{\circ} \mathrm{E}$ play more important roles than the atmospheric circulations at low latitudes during 1996-2014. Since the variation of spring rainfall over the middle and lower reaches of the Yangtze River valley is more sensitive to the mid- and high-latitude systems, the intensity of the spring rainfall over the middle and lower reaches of the Yangtze River valley is stronger than that over South China.

In addition, Chen et al. (2017) attributed the increase in intensity of interannual variation of summer precipitation over southern China around early 1990s to the change in the magnitude of SST anomalies over the southeastern tropical Indian Ocean. We wonder whether there is the notable change in the magnitude of SST anomalies in regions other than the western Pacific region, which is related to the interdecadal change of spring rainfall over South China. We further examined the regressed global SST (figure not shown) with respect to the interannual component of spring precipitation over South China during 1979-95. We can find there are 
(a) Surface Flux SIC P01-CTL
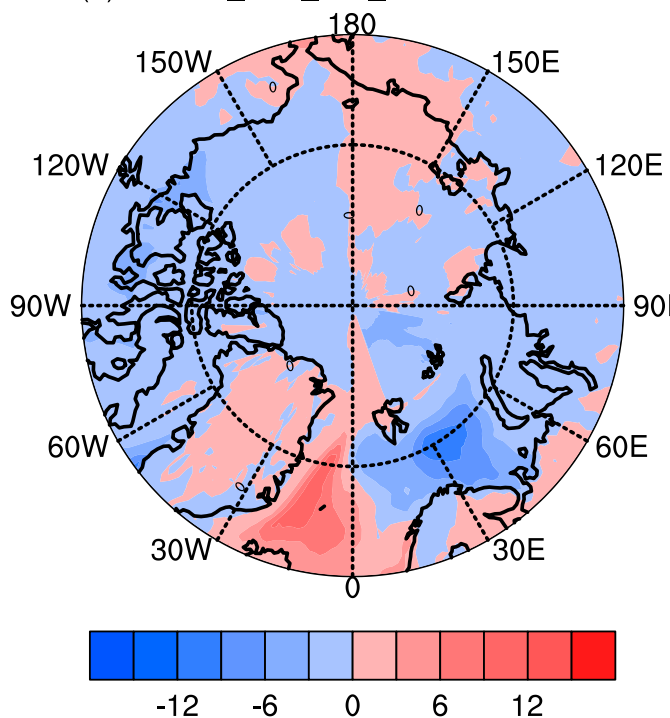

(c) HGT500_WAF_SIC_P01-CTL
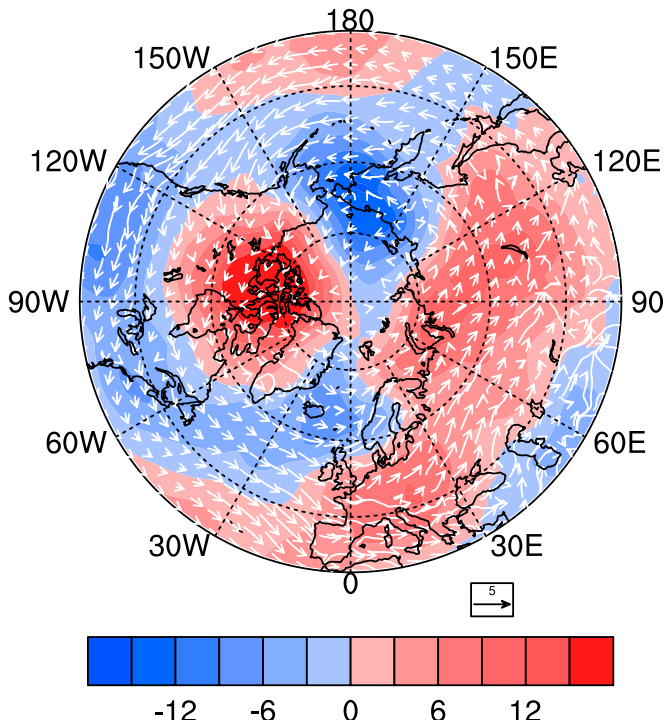

(b) Surface Flux SIC P01-P005
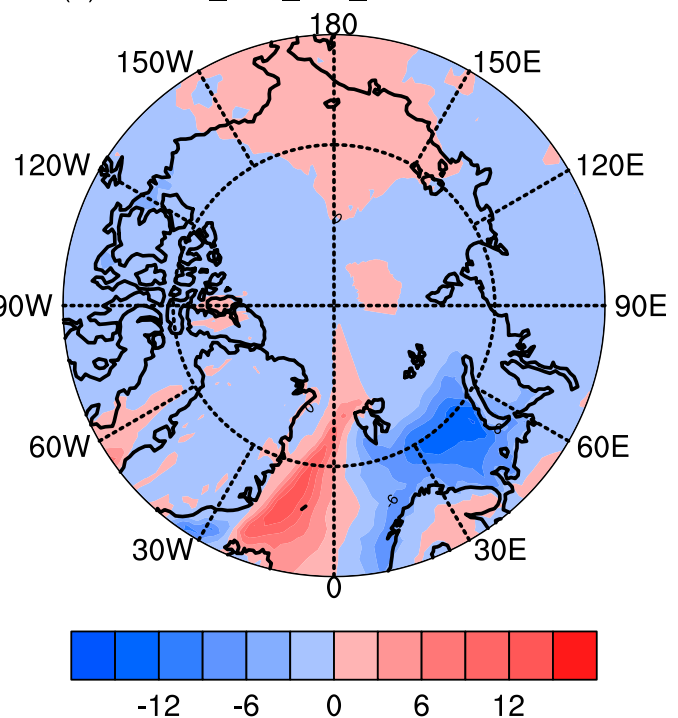

(d) HGT500_SIC_P01-P005
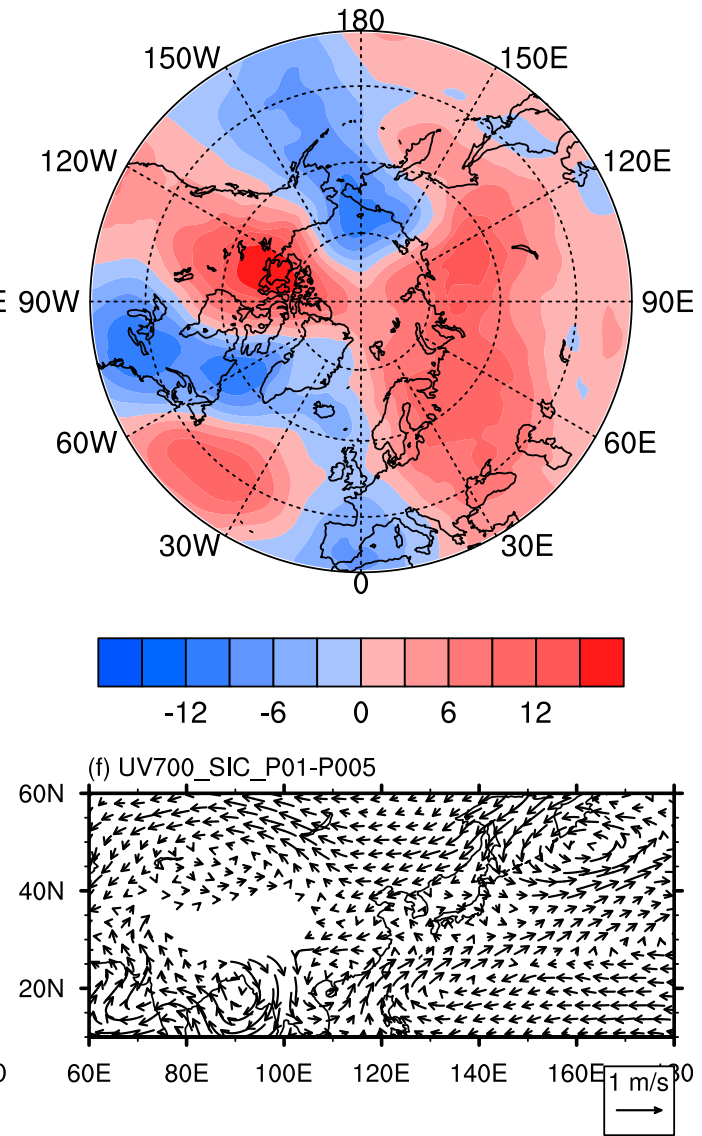

FIG. 13. Composite differences of (a),(b) surface heat flux ( $\mathrm{W} \mathrm{m}^{-2}$; positive: upward), (c),(d) 500-hPa geopotential height (shaded; gpm) and wave activity flux (vectors; $\mathrm{m}^{2} \mathrm{~s}^{-2}$ ), and (e),(f) $700-\mathrm{hPa}$ winds $\left(\mathrm{m} \mathrm{s}^{-1}\right)$ between (left) the SIC_P01 experiment and control run and (right) the SIC_P005 experiment. The wave activity flux in (c) is the result of SIC_P01 experiment instead of the difference. Outer circles in (a) and (c) are $65^{\circ}$ and $35^{\circ} \mathrm{N}$, respectively. 
three key regions in the tropical Indo-Pacific Ocean. The first one is the WP region, which we have discussed in the manuscript, the second one is the tropical eastern Pacific, and the third one is the tropical eastern Indian Ocean. We examined the time series of the average SST over the tropical eastern Pacific and the tropical eastern Indian Ocean, respectively. However, we did not find obvious interdecadal changes of the amplitudes of tropical eastern Pacific SST and tropical eastern Indian Ocean SST. Thus, we do not think the tropical eastern Pacific SST and tropical eastern Indian Ocean SST are the factors inducing the interdecadal change of the intensity of the spring rainfall over South China. In the manuscript, we just consider the WP SST as the important factor influencing the interdecadal change of the intensity of South China spring rainfall and explore how the WP SST influences the South China spring rainfall.

There are also other factors influencing the spring rainfall over southern China such as MJO, NAO, and snow cover over the Eurasian continent, as mentioned in the introduction. The present study does not examine whether these factors make a significant contribution to the interdecadal change in the intensity of interannual variation of spring precipitation over southern China. In this paper, we put March, April, and May together to consider the feature of the intensity of interannual variation in spring precipitation over southern China. However, even in spring, the features of precipitation and related atmospheric circulation in different months are distinctive.

Acknowledgments. The authors thank four anonymous reviewers for their comments, which have greatly improved the manuscript. This work is jointly supported by the National Key Research and Development Program of China (Grant 2016YFA0600601), the National Natural Science Foundation of China (Grant 41575069), and the Jiangsu Collaborative Innovation Center for Climate Change.

\section{REFERENCES}

Bai, X., C. Li, Y. Tan, and Z. Guan, 2011: Analysis of the MaddenJulian Oscillation impacts on the spring rainfall in east China. J. Trop. Meteor., 27, 814-822, https://doi.org/10.3969/j.issn. 1004-4965.2011.06.004.

Chen, J., Z. Wen, R. Wu, Z. Chen, and P. Zhao, 2014: Interdecadal changes in the relationship between southern China winterspring precipitation and ENSO. Climate Dyn., 43, 1327-1338, https://doi.org/10.1007/s00382-013-1947-x.

,$--\longrightarrow$, X. Wang, C. He, and Z. Chen, 2017: An interdecadal change in the intensity of interannual variability in summer rainfall over southern China around early 1990s.
Climate Dyn., 48, 191-207, https://doi.org/10.1007/s00382-0163069-8.

Cheng, Z., Y. Qiao, M. Jian, and S. T. Siems, 2018: Inter-decadal change of leading pattern of spring rainfall over southern China during 1901-2010. Int. J. Climatol., 38, 3494-3512, https://doi.org/10.1002/joc.5511.

Dee, D. P., and Coauthors, 2011: The ERA-Interim reanalysis: Configuration and performance of the data assimilation system. Quart. J. Roy. Meteor. Soc., 137, 553-597, https://doi.org/ 10.1002/qj.828.

Ding, Y.-H., 1992: Summer monsoon rainfalls in China. J. Meteor. Soc. Japan, 70, 373-396, https://doi.org/10.2151/jmsj1965.70. 1B_373.

Fan, K., Z. Xu, and B. Tian, 2014: Has the intensity of the interannual variability in summer rainfall over South China remarkably increased? Meteor. Atmos. Phys., 124, 23-32, https:// doi.org/10.1007/s00703-013-0301-5.

Fu, Y., 2013: The projected temporal evolution in the interannual variability of East Asian summer rainfall by CMIP3 coupled models. Sci. China Earth Sci., 56, 1434-1446, https://doi.org/ 10.1007/s11430-012-4430-3.

_ 2015: The relationship between the interdecadal variation of summer precipitation and its interannual variability over the middle and lower reaches of the Yangtze River valley. Atmos. Oceanic Sci. Lett., 8, 127-133, https://doi.org/10.3878/ AOSL20140098.

Gent, P. R., and Coauthors, 2011: The Community Climate System Model version 4. J. Climate, 24, 4973-4991, https://doi.org/ 10.1175/2011JCLI4083.1.

Honda, M., J. Inoue, and S. Yamane, 2009: Influence of low Arctic sea-ice minima on anomalously cold Eurasian winters. Geophys. Res. Lett., 36, L08707, https://doi.org/10.1029/ 2008 GL037079.

Jia, X., D. R. Cao, J. W. Ge, and M. Wang, 2018: Interdecadal change of the impact of Eurasian snow on spring precipitation over southern China. J. Geophys. Res., 123, 10 092-10108, https://doi.org/10.1029/2018JD028612.

Jiang, P., and P. Zhao, 2012: The interannual variability of spring rainy belt over southern China and the associated atmospheric circulation anomalies. Acta Meteor. Sin., 70, 681-689, http:// dx.doi.org/10.11676/qxxb2012.055.

Li, C., and Q. Zhang, 2013: The circulation characteristics of spring precipitation anomalies over the Yangtze River valley and their response to the preceding SSTA. Acta Meteor. Sin., 71, 452-461, http://dx.doi.org/10.11676/qxxb2013.033.

Li, J., X. Pan, Z. Zhang, D. Chi, and S. Min, 2016: Diagnostic analysis of moist potential vorticity for a rainstorm in North China. Torrential Rain and Disasters, 35, 158-165, https:// doi.org/10.3969/j.issn.1004-9045.2016.02.008.

Liu, G., J. Zhu, K. Yang, and K. Yang, 2015: Frequency features of spring continuous rain over southern China and its previous circulation signals. J. Meteor. Sci., 35, 474-479, https://doi.org/ 10.3969/2015jms.0029.

Lu, R., and Y. Fu, 2010: Intensification of East Asian summer rainfall interannual variability in the twenty-first century simulated by 12 CMIP3 coupled models. J. Climate, 23, 33163331, https://doi.org/10.1175/2009JCLI3130.1.

Mysak, L. A., and S. A. Venegas, 1998: Decadal climate oscillations in the Arctic: A new feedback loop for atmosphere-ice-ocean interactions. Geophys. Res. Lett., 25, 3607-3610, https:// doi.org/10.1029/98GL02782.

Neale, R. B., J. Richter, S. Park, P. H. Lauritzen, S. J. Vavrus, P. J. Rasch, and M. Zhang, 2013: The mean climate of the Community 
Atmosphere Model (CAM4) in forced SST and fully coupled experiments. J. Climate, 26, 5150-5168, https://doi.org/10.1175/ JCLI-D-12-00236.1.

North, G. R., T. L. Bell, R. F. Cahalan, and F. J. Moeng, 1982: Sampling errors in the estimation of empirical orthogonal functions. Mon. Wea. Rev., 110, 699-706, https://doi.org/10. 1175/1520-0493(1982)110<0699:SEITEO > 2.0.CO;2.

Qian, W., and D. K. Lee, 2000: Seasonal march of Asian summer monsoon. Int. J. Climatol., 20, 1371-1386, https://doi.org/ 10.1002/1097-0088(200009)20:11<1371::AID-JOC538>3.0. $\mathrm{CO} ; 2-\mathrm{V}$.

Rayner, N. A., D. E. Parker, E. B. Horton, C. K. Folland, L. V. Alexander, and D. P. Rowell, E. C. Kent, and A. Kaplan, 2003: Global analyses of sea surface temperature, sea ice, and night marine air temperature since the late nineteenth century. J. Geophys. Res., 108, 4407, https://doi.org/10.1029/2002JD002670.

Shao, T., and Y. Zhang, 2012: Influence of winter North Atlantic Oscillation on spring precipitation in China (in Chinese). Plateau Meteor., 31, 1225-1233.

Sun, B., and H. Wang, 2013: Larger variability, better predictability? Int. J. Climatol., 33, 2341-2351, https://doi.org/10.1002/ joc.3582.

Takaya, K., and H. Nakamura, 2001: A formulation of a phaseindependent wave-activity flux for stationary and migratory quasigeostrophic eddies on a zonally varying basic flow. J. Atmos. Sci., 58, 608-627, https://doi.org/10.1175/15200469(2001)058<0608:AFOAPI > 2.0.CO;2.

Wallace, J. M., and D. S. Gutzler, 1981: Teleconnections in the geopotential height field during the Northern Hemisphere winter. Mon. Wea. Rev., 109, 784-812, https://doi.org/10.1175/ 1520-0493(1981)109<0784:TITGHF>2.0.CO;2.

Wan, R., B. Zhao, and G. Wu, 2009: New evidences on the climatic causes of the formation of the spring persistent rains over southeastern China. Adv. Atmos. Sci., 26, 1081-1087, https:// doi.org/10.1007/s00376-009-7202-z.

Wang, B., R. Wu, and X. Fu, 2000: Pacific-East Asian teleconnection: How does ENSO affect East Asian climate? J. Climate, 13, 1517-1536, https://doi.org/10.1175/1520-0442(2000) $013<1517$ :PEATHD $>2.0$. CO 2 .

Wu, B., R. Huang, and D. Gao, 1999: The impact of variation of sea-ice extent in the Kara Sea and the Barents Sea in winter on the winter monsoon over East Asia. Chin. J. Atmos. Sci., 23, 267-275.
Wu, G., Y. Cai, and X. Tang, 1995: Moist potential vorticity and slantwise vorticity development. Acta Meteor. Sinica, 53, 387404.

Wu, R., and B. P. Kirtman, 2007: Observed relationship of spring and summer East Asian rainfall with winter and spring Eurasian snow. J. Climate, 20, 1285-1304, https://doi.org/10.1175/ JCLI4068.1.

$\mathrm{Wu}, \mathrm{X}$., and J. Mao, 2016: Interdecadal modulation of ENSOrelated spring rainfall over South China by the Pacific Decadal Oscillation. Climate Dyn., 47, 3203-3220, https://doi.org/ 10.1007/s00382-016-3021-y.

Yang, F., and K.-M. Lau, 2004: Trend and variability of China precipitation in spring and summer: Linkage to sea-surface temperatures. Int. J. Climatol., 24, 1625-1644, https://doi.org/ 10.1002/joc.1094.

Zhang, J., T. Zhou, R. Yu, and X. Xin, 2009: Atmospheric water vapor transport and corresponding typical anomalous spring rainfall pattern in China. Chin. J. Atmos. Sci., 33, 121-134.

Zhang, R., and B. Wu, 2011: The Northern Hemisphere atmospheric response to spring Arctic sea ice anomalies in CAM3.0 model. Chin. J. Atmos. Sci., 35, 846-862.

Zhang, T., and W. You, 2010: The distribution feature of spring rainfall and its relation to circulation anomaly in China. J. Yunnan Univ., 32, 553-560.

Zhou, T.-J., and R.-C. Yu, 2005: Atmospheric water vapor transport associated with typical anomalous summer rainfall patterns in China. J. Geophys. Res., 110, D08104, https://doi.org/ 10.1029/2004JD005413.

Zhu, Z., T. Li, and J. He, 2014: Out-of-phase relationship between boreal spring and summer decadal rainfall changes in southern China. J. Climate, 27, 1083-1099, https://doi.org/10.1175/JCLID-13-00180.1.

Zuo, Z., and R. Zhang, 2012: The anomalies of spring rainfall in eastern China and its relation with tropical Pacific SST and Eurasian snow. Chin. J. Atmos. Sci., 36, 185-194.

$\longrightarrow,-\ldots$, and B. Wu, 2012a: Inter-decadal variations of springtime rainfall over southern China mainland for 1979-2004 and its relationship with Eurasian snow. Sci. China Earth Sci., 55, 271-278, https://doi.org/10.1007/s11430-011-4337-4.

, — _ — , and X. Rong, 2012b: Decadal variability in springtime snow over Eurasia: Relation with circulation and possible influence on springtime rainfall over China. Int. J. Climatol., 32, 1336-1345, https://doi.org/10.1002/joc.2355. 